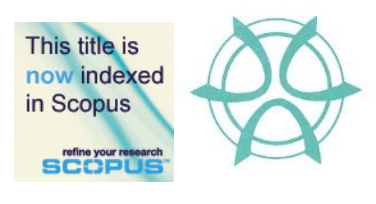

PLANNING MALAYSIA:

Journal of the Malaysian Institute of Planners

VOLUME 18 ISSUE 3 (2020), Page 202 - 217

\title{
URBANISATION AND THE CONCERNS FOR FOOD SECURITY IN MALAYSIA
}

\author{
Azizan Marzuki ${ }^{1}$ \& Ahmad Sahir Jais ${ }^{2}$ \\ ${ }^{1,2}$ School of Housing, Building \& Planning \\ UNIVERSITI SAINS MALAYSIA
}

\begin{abstract}
Urbanization is an effect of population growth. Increasing population contributed to the expanding of urban areas as cities try to accommodate more people within a minimal landscape. Urbanization takes up valuable land, sometimes productive agricultural land that feeds the population. The objectives of this paper are to investigate the connection between urban sprawl and its impact on agricultural productivity, and ultimately whether it affects food security in Malaysia. For this qualitative exploratory review exercise, a Systematic Literature Review (SLR) of secondary data was employed as the base for this study. Data mining techniques were used to gather relevant literature that included archival data, academic writings, and publications. The data are then dissected, analysed, and clustered using Atlas ti 8 software, focusing on thematic analysis. Urbanisation did affect the self-sufficiency level (SSL) of Malaysian food security, especially on landintensive food products such as vegetables and livestock. Recent government initiatives such as urban farming, land use policies were promoted to reduce the differences in food imports, ensuring Malaysian food security to be at an acceptable level. Significant development of this population-dense proximity has created urban sprawl beyond the city limits, taking up valuable land space. Landuse conversion from agricultural land in Malaysia has been studied regarding its adverse effects on agricultural production. Urbanization therefore does affect food security through the land conversion of agricultural lands.
\end{abstract}

Keywords: Urbanisation, Food Security, Land Use Policy, Agricultural Production 
PLANNING MALAYSIA

Journal of the Malaysia Institute of Planners (2020)

\section{INTRODUCTION}

It is a herculean challenge to ensure food security in the face of continuous urbanisation (Ismail Bakar, Agriculture and Agro-Based Industry Ministry Secretary-General as cited in Bernama (2018)). For the challenges to be met, it must be observed from three perspectives, which are Food Supply, Food Demand and Interaction between Supply and Demand. On the food supply and demand narratives, significant issues arise, where competition for limited resources occurs as cities stretched and agricultural land converted into residential or industrial areas (Bernama, 2018). Arable land as any other natural resources is limited and exhaustible. Malaysia faces competition for land space between urbanisation and agricultural usage (Gumma et al., 2017). Located in SouthEast Asia, it is among the most developed nations in the region, with a population of 32,385,000 inhabitants in 2018, spanning both Peninsular and East Malaysia (Sarawak and Sabah). Annual population growth rate marked steadily in between the bottom of 1.1 per cent, to the highest 2.4 per cent annually since the year 2010. The median age group is 28.6, which indicates the resiliency in Malaysian age-group and workforce supply (Department of Statistics Malaysia, 2018b).

The Malaysian economy has shown remarkable diversification from the early days of independence, where agriculture and natural resources were the mainstays of the economy, before moving to industry-based economies. Malaysia went full-steam ahead with the industrialisation of its economy in the early ' 70 s, '80s and '90s (Samat et al., 2014; Yaakob et al., 2010). The economy is currently moving away from the primary industry towards downstream and value-added production and manufacturing. This surge has created tremendous job opportunities in urban areas, hence the continuous influx of migration from rural areas, which kick-started the urbanisation boom. In the process, smaller towns became cities and cities became mega conurbations as illustrated in the case of Klang Valley, Johor Bahru, and Georgetown. As of 2010, 70 per cent of the Malaysia population live in urban areas (Department of Statistics Malaysia, 2018a; Yaakob et al., 2010). Peninsular Malaysia is more urbanised than in East Malaysia (Sabah and Sarawak). Peninsular Malaysia presently has about 70 per cent of its population living in urban areas as compared with Sabah and Sarawak with 48 per cent and 48.1 per cent, respectively (Gumma et al., 2017). The aims of this paper are to investigate and answer pertinent propositions - whether land conversion due to the urban sprawl is a critical issue, Secondly, to assess whether there is a correlation between urban sprawl and agricultural productivity and finally, to assess the effects of land conversion to food security in Malaysia.

\section{LITERATURE REVIEWS}

Urbanisation is seen as a distinct sign of growth and modernity; notwithstanding, urbanisation is not without its ugly sides (Olaniyi et al., 2013). Studies have shown the multifaceted impact of urbanisation on social, environmental, and 
Azizan Marzuki \& Ahmad Sahir Jais

Urbanisation and The Concerns for Food Security in Malaysia

economic aspects. Social and environmental impact of urbanisation has been studied over the years (Chase Sova, 2018; Dadi et al., 2016; Gumma et al., 2017; Rosni \& Mohd Noor, 2016; Siong, 2008; Tripathi \& Rani, 2017; Yaakup et al., 2008). Urban sprawl, as an outcome of urbanisation, is one of them. In order to accommodate more urban inhabitants, a new development was forced upon the surrounding environments to facilitate the mobility and movement of the city dwellers.

Movement and mobility of urban inhabitants can be predicted (Chapin, 1974). Most often, they move in conjunction with significant transport networks such as roads, highways, train tracks, etc. (Ewing, 1994). In urban areas, the core of the built-up areas has mostly been taken up by commercial development. Kuala Lumpur for example, is the centre of commerce and administrative capital for the federal government. Rapid development and economic booms in the early ' $80 \mathrm{~s}$ and '90s have resulted in uncontrolled development (Abdullah et al., 2009). Squatters and slums were cropping up at the urban fringe, catering for those who were unable to afford expensive houses, which mostly comprised the Malay ethnicity (Bakeri et al., 2017). This happened due to the city centre being taken up by commercial buildings, increasing its land value tremendously. For example, the Klang Valley is geographically constrained on both sides, with mountain ranges to the east and west, and new townships or satellite towns were constructed to alleviate the stress on Kuala Lumpur. More urban areas were annexed to the Klang Valley, providing accommodation and housing, and the annexation of the new township created the Greater Klang Valley Conurbation. Land that was previously set aside for tin mining and agriculture, rubber plantation and palm oil plantation has been converted to housing estates and commercial development, all to cater for the urban population.

Living in urban areas poses a few challenges, and among others is the issue of creating sustainable food security (World Food Program, 2017). The United Nation's (UN) International Fund for Agricultural Development (IFAD), has fixed in their nutrition security frameworks, a food security element, where individuals have access to adequate food supplies as well as necessary prerogatives to healthcare and personal hygiene, in a hygienic environment (Jennings et al., 2015). Land space is considered a natural resource and is inadequate in supply. Competition for valuable land space, to provide hospitable living to every urban resident is more pressing than ever. Urbanisation also has adverse consequences with regard to the distribution of the population and the enormous demands for land, water, housing, transport and employment (Siong, 2008). The dynamic between urban and rural spaces is some of the issues faced in urbanisation. The interrelation between urban and rural areas works on so many levels, which lead to disengagement between user-production-producer (Jennings et al., 2015). Food is already packed and processed when it reaches the consumer. Rural areas are marked to be the suppliers of cheap food for urban 
consumers, thus changing its purpose beyond economies of scale. The increasing demand for food of the urban inhabitants, changes in their diets and the changes in the food supply chains and operators all have implications both in the city and the rural areas (Jennings et al., 2015).

Food security is an intricate, multi-layered issue influenced by culture, environment and geographic location (The Economist Intelligence Unit, 2017). For example, findings indicate that as a result of urbanisation-related, land-use change, together with high applications of fertiliser, most of Europe's freshwater bodies have been contaminated (Kuuskorpi \& Gonzalez, 2011). The Food and Agricultural Organization (FAO) defines food security as "a situation which permits all people, at all times, to have physical and economic access to sufficient, safe and nutritious food to meet their dietary needs and food preferences for an active and healthy life" (FAO 1996). Four dimensions that exist in food security are availability, stability, safety, and access.

\section{METHODOLOGY}

A qualitative approach was adopted as the research paradigm by incorporating a Systematic Literature Review (SLR) method and Thematic Analysis. Data mining procedures using Keywords in Context (KWIC) (Luhn, 1966) to find a "lead" and then flowed by "snowball techniques" (Wohlin, 2014) were used to create an initial raw data. Keywords were used to find the lead references, incorporate Boolean Operator in data archives (Data repository such as resource centre at the Ministry of Agro-based Industry (MoA)), printed publications and also through online-based archives. 150 data sets comprising periodicals, production data, research journals, annual reports, newspaper, and magazine articles were collected. The raw data were then analysed using thematic analysis using qualitative analysis software, Atlas ti. 8. For this, data in the electronic format were screened using "Word Cloud Techniques" (Tessem et al., 2015) to assess discerning word patterns. Repetition of specific phrases such as Food Security, Urban Sprawl, Land Use, Land Conversion, Agricultural Productivity were flagged. Inclusion criteria with specific keywords were used as the parameter for the search. Only 73 works of literature references were found to be useful for this study.

The narratives of this paper are presented according to the emerging theme, distinguished as part of this SLR. The theme includes 1) the relationship and effects of urbanisation toward food security in Malaysia, and 2) the issues of land conversion and urban sprawl. The discussions were posited into three argumentative enquiries; firstly, does land conversions and urban sprawl affect urbanization as a critical issue in Malaysia. Secondly, are there any direct linkages between land conversion practices and urban sprawl within the context of agricultural productivity, and thirdly, is food security affected in any way by these practices. 
Azizan Marzuki \& Ahmad Sahir Jais

Urbanisation and The Concerns for Food Security in Malaysia

\section{RESULTS \& ANALYSIS}

The discussions encompass the commonality between food security and urbanisation, urban growth and food security from the Malaysian context and the initiatives for food security to increase urbanisation.

\section{Urbanisation and Land Conversion Practices in Malaysia}

Two distinctive narratives need to be fully understood in order to picture a link between urbanisation and food security. It is also imperative to understand the underlying factors contributing to the process of urbanisation growth as a dynamic, persistent process, yet governable to a certain extent. The first narratives are the urbanisation process itself, and what propagates urbanisation to the point of being seen as a threat to sustainable living. Urbanisation is the process of physical growth of urban areas. In Malaysia, an urban area is defined as a gazetted area with their adjoining built-up areas, having a combined population of 10,000 or more. 60 percent of the population of that gazetted area (aged 15 and above) must engage in non-agricultural activities to be acknowledged as urban areas (Department of Statistics Malaysia, 2018a).

Its distinctive feature can characterise urban development in Malaysia. As most urban centres are unplanned initially (Majid \& Yahya, 2010), the morphology of its terrain and land composition can be described using its landuse zoning (McHarg, 1969). Most urban cities in Malaysia consist of several layers, as shown in Figure 1. Core zone comprises a commercial building, while the outer layer comprises the commuting zone, where urban inhabitants ply to work every day to the core zone.

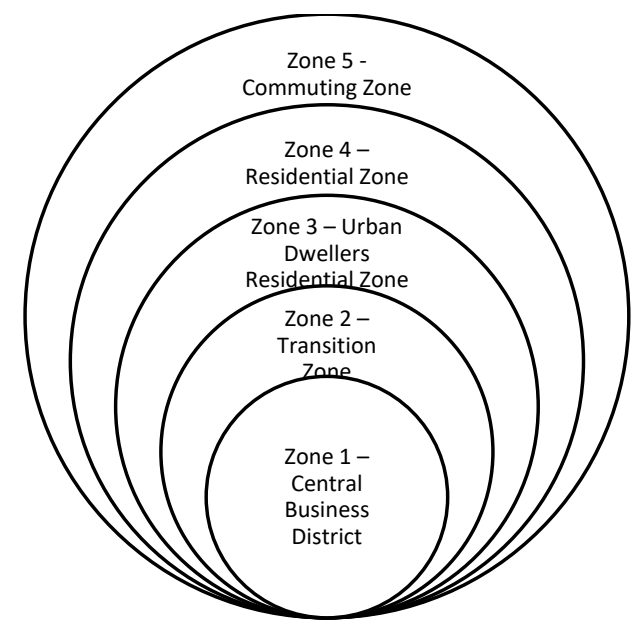

Figure 1: Urban Land Use According to Zoning Source: Adapted from McHarg (1969) 
Population growth is principally due to the process of migration from rural areas to urban areas. However, research also indicates that much of the urban growth is due to natural growth, such as higher birth rate than mortality rates (Matuschke, 2009). In the ' 70 s and ' 80 s, the government encouraged rural Malays to migrate to urban areas to offset the racial imbalances in those areas (Siong, 2008). In some areas, the rural areas become the urban areas itself because of population explosion. Further, better economic, and social development opportunities motivate the migration from rural to urban areas. Research also indicates that better education levels among the rural communities meant the lack of suitable jobs and work opportunities in rural areas forced them to migrate to the cities (World Food Program, 2017).

In Figure 2, the correlation between urban and rural population growth in Malaysia undeniably supports the assumption. The current population, which already populates the urban areas, has decreased the rural population. Urban dwellers' quest for fundamental needs, such as housing and food, became pertinent issues that needed to be accommodated by town planners. City centres, where most of the commercial areas were located, were no longer able to support the influx and growth of the population, thus making the city move outwards beyond its intended footprints (Rashid \& Ghani, 2007).

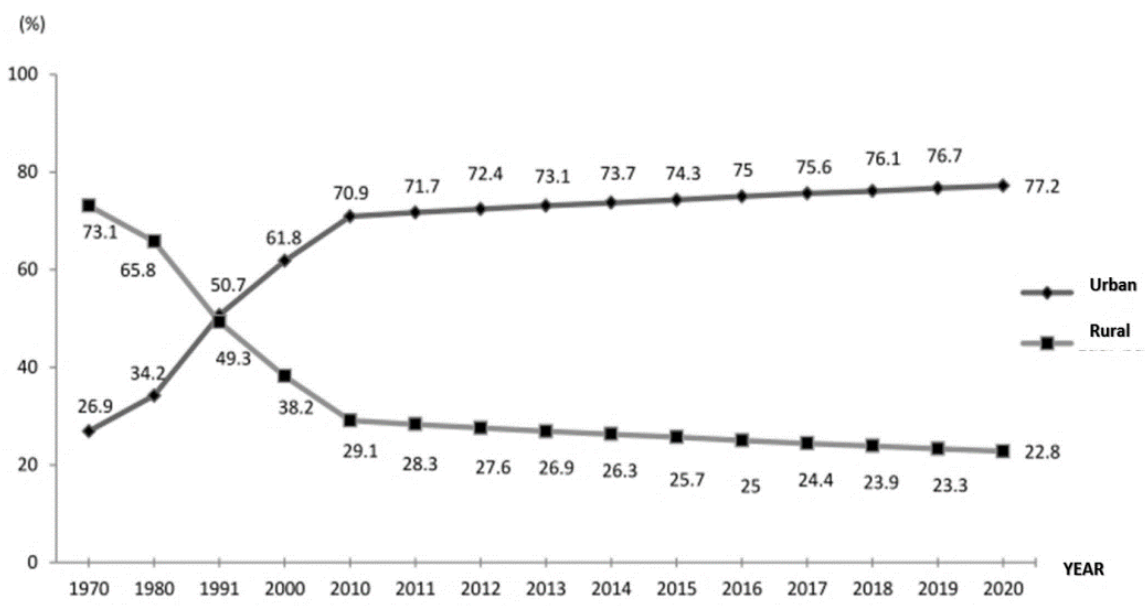

Figure 2: Malaysia Population Distribution Urban Versus Rural Area, 1970-2020 Source: Data aggregated from the Ministry of Rural and Regional Development (2015)

This outward movement of built-up areas often follow a particular corridor, such as following major transport networks like main roads, highways, trains tracks and riverfronts. Another characteristic of this movement is that it tends to move away from the core section of the built-up areas, resulting in the decrease of the population within the core areas as cited by Siti Zakiah Muhamad Isa (2007) in 
Azizan Marzuki \& Ahmad Sahir Jais

Urbanisation and The Concerns for Food Security in Malaysia

Yaakob et al. (2010). This is due to the high living cost, and a decreased life quality. Most migrants tend to stay at the urban fringe while commuting to their work daily as cheaper housing options, better and newer facilities, added with the use of personal transport, have resulted in the urban dwellers moving further away from the urban centre (Rashid \& Ghani, 2007).

This movement, if unchecked and not adequately planned, will lead to urban sprawl (Majid \& Yahya, 2010). The connection of urban sprawl and losses of agriculturally productive lands have been thoroughly documented (Chase Sova, 2018; Dadi et al., 2016; Duran et al., 2012; Gumma et al., 2017; Heimlich \& Anderson, 2001; Osman et al., 2012; Samat et al., 2014; Samat et al., 2012; Wilson \& Chakraborty, 2013). Direct linkages have been proven between these two, either the relationships supporting or inverted (Seto \& Ramankutty, 2016).

The second narratives are the relationship of urbanisation affecting land use. The transformation of non-developed areas into built-up areas has created significant changes in the physical land space as well as in the socio-economic situation (Samat et al., 2012) (Osman et al., 2012). Land-use conversion is an after-effect of urbanisation, where land resources are scarce. In order to meet the demand of the population, available land spaces were turned for development purposes. In most cases, lands marked for agricultural activities were the first to be converted, as opposed to already inhabited land spaces. Samat et al. (2014) in their research of urban expansion in Seberang Perai, Penang countryside uncovered some interesting findings. They deduced that local communities have more employment opportunities and experienced a better quality of life from urban development. Inadvertently however, the growth of built-up areas has put pressure on land. Consequently, this has caused significant loss of agriculture land, affecting the likelihood of the farming communities at the peri-urban areas (Samat et al., 2014). Ultimately, continuous land conversions threaten the existence of agriculture that provides staple food mainly rice to large communities in both rural and urban areas.

\section{Urbanization versus Agricultural Productivity}

For this study, the paddy production output for rice is used to visualize the relationship between urbanization and agricultural productivity. Figure 3 visualised the correlation between urban growth rate, rice production and rice imports over the last four decades. The urban growth rate for the last four decades has shown an upward trend, consistently. In the 1980s, urban growth rate stood at 34.2 per cent, rising steadily to 71 per cent in 2010 (2010 was the last national census; the next census will be in 2020). When compared to the rice production per capita within the same timeline, it trended towards a downward movement. Rice production ( $\mathrm{kg} /$ person/year) in $1980 \mathrm{stood}$ at $79 \mathrm{~kg}$ per person annually but reduced to $59 \mathrm{~kg}$ in 2010. While this is happening, rice imports have risen relative to the downwards production of rice. On average, Malaysia imported $29.2 \mathrm{~kg}$ of 
rice per person. Taking this into consideration, Figure 4 shows paddy planting areas in hectare versus productivity throughout fifteen years (Arshad et al., 2011). From the graph, the productivity of paddy crop in tonne has shown an upward trend. Although there are several fluctuations in productivity, it is still comparatively higher, notwithstanding the lower hectarage of paddy planted areas. The size of hectarage of paddy planting areas has also shown significant downsizing, albeit remaining consistent.

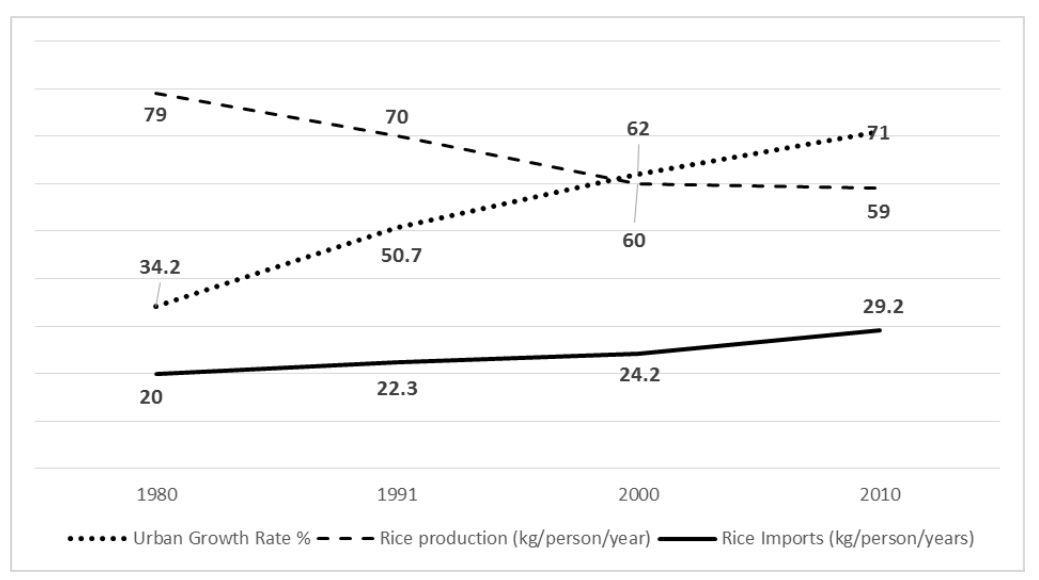

Figure 3: Correlation between urban growth, Rice production and Rice Imports Source: Data aggregated and synthesizes from the Department of Agriculture Peninsular Malaysia, (2015); Ministry of Rural and Regional Development (2015); Rezai, Shamsudin, \& Mohamed (2016)

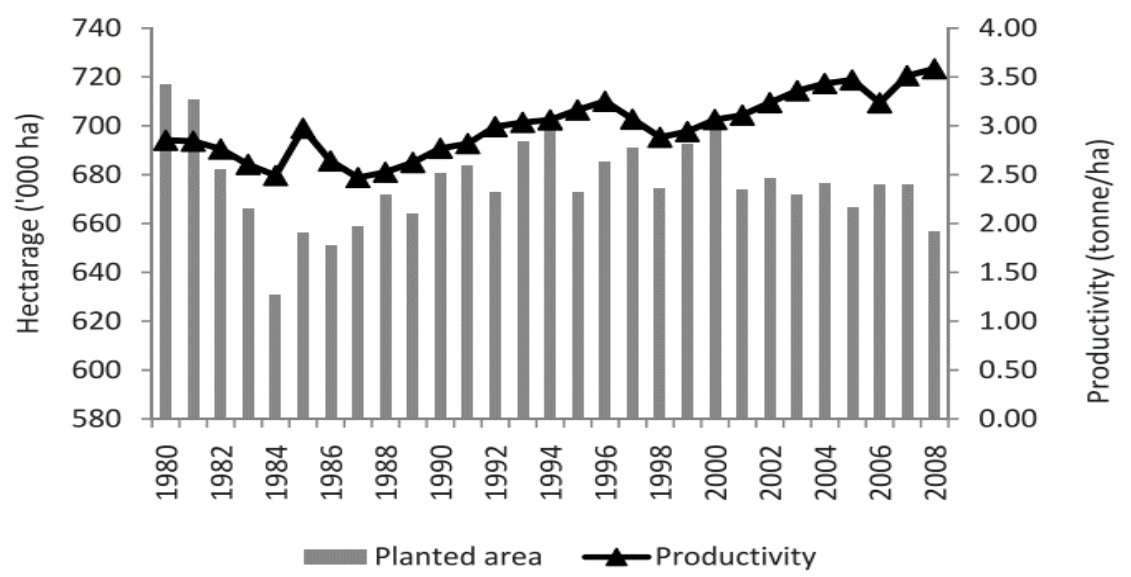

Figure 4: Paddy Planted Area versus Paddy Productivity Source: Arshad et al. (2011) 
Azizan Marzuki \& Ahmad Sahir Jais

Urbanisation and The Concerns for Food Security in Malaysia

In comparison, data in Figure 3 and Figure 4 indicate some discrepancies, especially on the figure of rice production ( $\mathrm{kg} /$ person/year) with the overall productivity (tonne/ha). Even though rice productivity (tonne/ha) seemingly increases over the years, so does the population of Malaysia. The level of productivity, although rising, indicated inadequateness to provide a consistent supply of rice for the average Malaysian, thus increasing the volume of imported rice. Given the circumstances, the number of paddies planted areas is also decreasing, which inadvertently contributed to the inadequacy. This indicates that the productivity of rice, in general, is correlated to the growth in population. The loss of arable and usable land for agriculture can be offset by better crop and agricultural practices which provide adequacy in terms of food supply (Gumma et al., 2017).

\section{Effect of Urbanization, Land Conversion and Food Security}

The links between urbanisation and food production are concealed due to the lack of research and studies. Seto \& Ramankutty (2016) visualised the linkages of a known body of knowledge between urbanisation and the food system. They suggested that there were still hidden linkages between these two, especially on the areas of land use and built environment that needed to be understood and studied thoroughly. There is, however, clear evidence that suggests a direct linkage between built-up expansions and the loss of agricultural land in particular. Seto \& Ramankutty (2016) postulated a linkage between urbanisation and the food system. In their study, Seto \& Ramankutty (2016) produced evidence that supports land conversion as an effect of urban sprawl to the loss of agricultural land. Collective wisdom foresees that agricultural productivity is proportionate with the loss of agricultural land. As agriculture land size diminishes, it becomes unprofitable to work. The agricultural land became idle and unused to a point where farmers are willing to sell their land in the hope for a quick return (Samat et al., 2014). Foreseeably, land losses mean a reduction in agricultural production. The importance of the agricultural sector as a means of securing food security in Malaysia has been on the main agenda since independence. The Malaysia Plans (First to Eleventh) gave priority to agricultural development for achieving economic growth, especially in the first 15 years of the plan (1966-1980) (Olaniyi et al., 2013). 


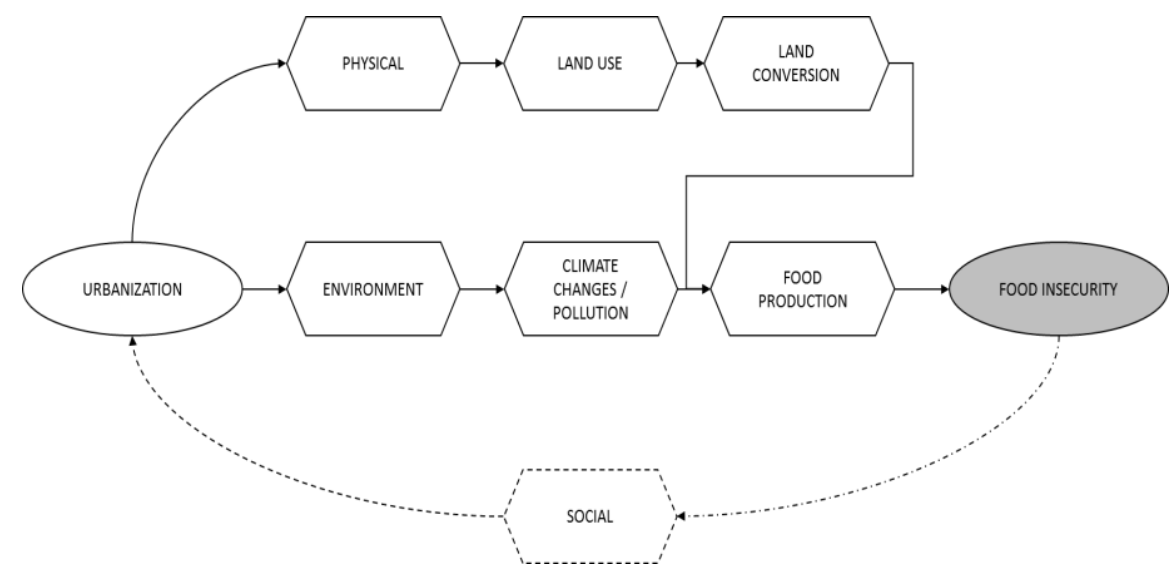

Figure 5: Urbanization and Food Security Linkage

Source: Synthesised from Beatly (2000); Rashid \& Ghani (2007); Naimah Samat et al. (2014) and World Food Program, FOA (2017)

Urbanisation has an impact on the physical and spatial use of the land, as shown in Figure 5. Much of it is due to the expansion of urban footprint, both controlled and uncontrolled. As discussed earlier, an after-effect of urbanisation is the expansion of the urban footprint itself. Available land space is converted from agricultural land to commercial and built-up areas. Much of the areas surrounding urban cities are gazetted as agricultural lands. For example, in the town of Seberang Perai in Penang, surrounding areas are designated as paddy farming areas. Being annexed as part of the Georgetown Conurbation, the urban footprint expanded much more significantly than it used to be. The repercussion was that much of the agricultural areas are converted for commercial and housing use (Samat et al., 2014). Losses of land, especially those primed for food production will eventually lead to food insecurity as shown in Figure 5.

Food insecurity can also move backwards, affecting the urbanisation process, contrary to the urbanisation process affecting the social stratum. In a recent report from the World Food Programme (WFP), it was suggested that for everyone per cent increase in food insecurity, an additional 1.9 per cent of people were compelled to migrate. Moreover, as more people migrate, they may hinder the ability to access, or have no resources, to purchase food on their journey, forcing them to continue moving (World Food Program, 2017). Urban areas attract these migrants due to better access to employment and other resources (Samat et al., 2014) rather than working in the agricultural sectors. These cycles therefore need to be addressed urgently. In the Malaysian context, studies by Rashid \& Ghani (2007) on the urban migration in the Klang Valley, supported the supposition of social factors affecting urbanisation. In the $1980 \mathrm{~s}$, the interaction of urban migration was inverse, in that there were streams of outward movements of population from the city centres to the urban fringes. 
Azizan Marzuki \& Ahmad Sahir Jais

Urbanisation and The Concerns for Food Security in Malaysia

The connection between urbanisation and food security is not solely based on a negative impact or adverse repercussion. The philosophy of urbanism encapsulates that the process of urbanisation itself shares a broader undertone, and should be observed holistically as a balance between progress and nature (Marzuki et al., 2016). Through organised, balanced, and systematic urbanisation, the noble values of preserving sensitive zones, environments and habitats could and should be ingrained in the planning process. Initiatives such as conservation, density control, land use planning and spatial design can be implemented to replace any resources consumed during urbanisation (McHarg, 1969). Beatly (2000) reiterated similar ideas, where in an ideal situation, well-planned urbanisation would lead to a city which is ecologically designed, with reduced ecological footprints, walkable and liveable. Most importantly, a well-planned city would be able to provide their population with food resources of their own and promote a holistically better living quality.

Better living quality means that urban inhabitants can access basic food quickly and affordably. For example, for the average Malaysian, access to rice, a daily staple, is a must. Rice production is an excellent example to illustrate and visualise the connection between urban growth and food security. Rice is a staple food in Malaysia where, on average, each Malaysia consumes $78 \mathrm{~kg}$ of rice per person annually (Department of Statistics Malaysia, 2018b). Malaysia is already known for its natural resources such as tin and petroleum, agro-products such as palm oil and rubber. Today, however, Malaysia remains a net importer of food, a fact difficult to comprehend given the country's origins and history, but one that needs to be thoroughly studied. It is indeed a monumental task to ensure food security in the advent of rapid urbanisation and include the possible impact of related challenges having dire consequences to the well-being of society. Critically, pertinent issues often raised by researchers and policymakers focus on the competition of resources as cities expand beyond its footprint, forcing the conversion of productive agricultural land into residential, commercial, or industrial areas. The base arguments are simple enough; land is a critical constituent of agriculture and without arable land means food crops cannot grow and raising livestock will be hindered. Agricultural production, while imparting a sense of security over food supplies, sometimes can be misleading. This false sense of security is premised further as not all agricultural products are used as food. Some are processed and reprocessed to become food and other industrial products. Palm oil and rubber, for example, are agricultural products, but not directly benefiting the population as it needs to be processed. In a report released by the Department of Statistic Malaysia, the Self-Sufficiency Level (SSL) in 2016 for selected food crops/ livestock and fisheries, surpassed the 100 per cent level. However, the crops had a low consumption rate per capita such as mango, jackfruit and tuna (The Office of Chief Statistician Malaysia, 2017). In the Malaysian context, a benchmark often used to gauge the Self-Sufficiency Level 
(SSL) and food security is rice production. Rice is a staple in Malaysia, where almost 70 per cent of the supplies were domestically cultivated. In order to sustain and maintain this high level of productivity, the government has inducted several interventions in comparison with other commodities such as palm oil, as financially, rice production yields lower returns per hectare (Arshad et al., 2011). To ensure the paddy fields from being turned to other agricultural commodities, the government subsidised the rice production heavily. Malaysia ranked at number 41 out of 113 countries in the global food security index (The Economist Intelligence Unit, 2017). The Self-Sufficiency Level (SSL) looks promising, notwithstanding the trade imbalance that still existed for food imports. Malaysia's SSL for certain food products show high levels of sufficiency for produce such as eggs $(119 \%)$, poultry $(103 \%)$, fish $(94.7 \%)$, fruits $(79 \%)$ and rice $(71.4 \%)$. However, the country is still lagging in regards to achieving a food security minimum threshold for specific essential items such as vegetables (48.3\%) and beef/buffalo meat (23.4\%) (Carvalho, 2018; The Office Of Chief Statistician Malaysia, 2017). The rice production level has achieved its intended target of SSL at $70 \%$ of domestic reliance, as stated in the Agro-Food Policy 2011-2020 (Arshad et al., 2011). Land use for food crops cultivation has been decreasing from 1960 to 2005, where land used for food is at 31.5 percent compared to 16.3 per cent of the total arable land (Olaniyi et al., 2013).

Malaysia once had an SSL for rice at 95 per cent in 1975, and this higher percentage was due to the strong government policies and initiatives, which encouraged paddy production. As urbanisation continues to grow rapidly, the reliance and sustainability on food supplies shift, from regional food supply chains towards a more globalised supply chain. This means that instead of multiple different suppliers being involved, the centralised supply chain has taken over, with a high proportion of already processed food, rather than raw materials being involved (Jennings et al., 2015). As mentioned, Malaysia was ranked 41 out of 133 nations in terms of self-reliance on food. However, this reliance is not wholly comprehensive, and in some aspects of food production, the country still lags. Over dependency on specific regions for food production in Malaysia has had an adverse impact on its food security. For example, rice is mainly cultivated to the northern Malaysian peninsular, accounting for almost 34 per cent of the national rice production while Cameron Highlands remain the nation's salad bowl, where almost 20 percent of domestic vegetables come from (NoranizaYusoff, 2015). Apart from these two significant areas, various food crops are cultivated across Malaysia, albeit on a small scale. For fisheries, the east coast of Peninsular Malaysia remains the top fisheries product landing areas.

As urban areas grew, compounded with the migration of the rural population, the supply of food often associated with the rural areas became disrupted. Workforce needed to cultivate, and harvest food-based agricultural products have moved out to seek better living, at the obvious expense of this 
Azizan Marzuki \& Ahmad Sahir Jais

Urbanisation and The Concerns for Food Security in Malaysia

sector. Cameron Highland, for instance, hired more than 13,000 immigrants, both legal and illegal from Bangladesh, India and Myanmar to cope with the demands of the agricultural produce there (Fernando \& Tasnim, 2018). For the past ten years, agriculture was thrusted back into the national development agenda. This resurgence is attributable to the government acknowledging the problem of food security and resiliency in the changing population structure. Among the initiatives to regenerate the agriculture sectors, the use of biotechnology, direct penetration to supply chain and re-engineering poverty through agriculture were leveraged upon (Wong, 2007). The biotechnology sectors were used primarily to promote better technology-driven practices in agricultural sectors and include the use of better and improvised seeds, livestock breeding and fisheries technologies, to improve productivity.

\section{CONCLUSION}

Urbanisation plays a causative role in the undermining of food security in Malaysia. It derives from the losses of agricultural land due to land conversion and urban sprawl. Although steady growth in agricultural productivity has been achieved due to better crop and agricultural management, land-loss is still impacting agricultural production, since the activities are land-intensive. As Malaysia attempts to be self-sufficient in terms of food production especially for staple crops such as rice, urbanisation and the movement of rural population due to migration have contributed to the lower agricultural yield, primarily due to the lack of workforce to work the land. It is thus imperative that government policies on food self-reliance must ensure that urbanisation does not impede or hinder food security, by ensuring that losses of valuable agricultural land are minimized.

\section{ACKNOWLEDGEMENT}

The publication of this article was supported by Ministry of Higher Education (MOHE) research grants. Fundamental Research Grant Scheme (FRGS) 203/PPBGN/6711555, Proses Rebakan Bandar dan Kesannya Terhadap Pengeluaran Hasil Pertanian. Kajian Kes: Daerah Kota Setar, Kedah, Ministry of Higher Education.

\section{REFERENCES}

Abdullah, J., Yahaya, M. Z., Yunus, M. Z. M., \& Safudin, M. S. M. A. (2009). Urban Sprawl in Malaysia : Evidence From Three Largest Metropolitan Areas. Journal of the Malaysian Institute of Planners, 7, 69-82.

Arshad, F. M., Alias, E. F., Noh, K. M., \& Tasrif, M. (2011). Food security: selfsufficiency of rice in malaysia. Ijms, 18(2), 83-100.

Azizan, M. U., Raid, M. M., \& Hussin, K. (2016). Urbanisation and Food Security : An Overview. Sains Humanika, 8(4-3), 71-75.

Bakeri, A., Ramli, Z., Choy, E. A., \& Awang, A. (2017). Rebakan Bandar Dan Kenaikan 
Harga Hartanah: Kajian Awal Impak Terhadap Masyarakat Melayu Pinggir Bandar Di Hulu Langat Selangor. In Z. Ramli, M. Hadrawi, A. Duli, K. Jusoh, \& M. S. M. Ali (Eds.), 6th International Seminar on Archeology, History and Cutural in the Malay World (Issue September, p. 900). Institut Alam dan Tamadun Melayu (ATMA) Universiti Kebangsaan Malaysia 43600.

Beatly, T. (2000). Green Urbanism: Learning From European City. Island Press.

Bernama. (2018). WUF: Challenge to ensure food security with rapid urbanization. The Malay Mail. https:/www.malaymail.com/s/1575739/wuf-challenge-to-ensurefood-security-with-rapid-urbanisation

Carvalho, M. (2018, July). Malaysia's food security ranks No. 2 in South East Asia. The Star. https:/www.thestar.com.my/news/nation/2018/07/26/malaysia-foodsecurity-ranks-no2-in-south-east-asia/

Chapin, S. F. (1974). Human activity patterns in the city; things people do in time and in space. John Wiley \& Sons, Inc. https://doi.org/9780471145639

Chase Sova. (2018). Increasing Urbanization Threatens Food Security In Africa | World Food Program USA. World Food Program USA. https:/www.wfpusa.org/articles/increasing-urbanization-threatens-food-securityafrica/

Dadi, D., Azadi, H., Senbeta, F., Abebe, K., Taheri, F., \& Stellmacher, T. (2016). Urban sprawl and its impacts on land use change in Central Ethiopia. Urban Forestry and Urban Greening, 16(February 2016), 132-141. https://doi.org/10.1016/j.ufug.2016.02.005

Department of Agriculture Peninsular Malaysia. (2015). Paddy Statistics of Malaysia 2014.

Department of Statistics Malaysia. (2018a). Population and Housing Census. Frequently Asked Question. https://www.dosm.gov.my/v1/index.php?r=column/cone\&menu_id=bDA2VkxR SU40STcxdkZ4OGJ0c1ZVdz09

Department of Statistics Malaysia. (2018b). Press Release - Current Population Estimates Malaysia 2017-2018 (Issue July). Department of Statistics Malaysia. https:/www.dosm.gov.my/v1/index.php?r=column/pdfPrev\&id=c1pqTnFjb29H SnNYNUpiTmNWZHArdz09

Duran, C., Gunek, H., \& Sandal, E. K. (2012). Effects of urbanization on agricultural lands and river basins: Case study of Mersin (South of Turkey). Journal of Environmental Biology, 33(April), 363-371.

Ewing, R. H. (1994). Characteristics, Causes, And Effects Of Sprawl: A Literature Review. Environmental and Urban Issues, 21(2).

Fernando, F., \& Tasnim, L. (2018, January). Labour Shortage in Cameron Highlands. The New Straits Times https://www.nst.com.my/news/exclusive/2018/01/327205/labour-shortagecameron-highlands

Gumma, M. K., Mohammad, I., Nedumaran, S., Whitbread, A., \& Lagerkvist, C. J. (2017). Urban sprawl and adverse impacts on agricultural land: A case study on Hyderabad, India. Remote Sensing, 9(11), 1-16. https://doi.org/10.3390/rs9111136

Heimlich, R. E., \& Anderson, W. D. (2001). Development at the urban fringe and beyond: 
Azizan Marzuki \& Ahmad Sahir Jais

Urbanisation and The Concerns for Food Security in Malaysia

Impacts on agriculture and rural land. In Agriculture Economic Report (Issue 803). https://doi.org/10.1111/1540-5834.00132

Jennings, S., Cottee, J., Curtis, T., \& Miller, S. (2015). Food in an Urbanized World:The Role of City Region Food Systems in Resilience and Sustainable Development. In UN Food and Agriculture Organization (Issue April). http:/www.fao.org/fileadmin/templates/agphome/documents/horticulture/crfs/fo odurbanized.pdf

Kuuskorpi, M., \& Gonzalez, N. C. (2011). The Future of the Physical Learning Environment: School Facilities that Support the User. \{CELE\} Exchange, 2006, 6. https://doi.org/10.1787/5kg0lkz2d9f2-en

Luhn, H. P. (1966). Key Word-In-Context Index for Technical Literature (KWIC Index). In D. G. Hayes (Ed.), Automatic Language Processing (pp. 288-295). American Elsevier Publishing Company Inc. https://doi.org/10.1002/asi.5090110403

Majid, M. R., \& Yahya, H. (2010). Sprawling of a Malaysian City: What Type and What Solutions. The First International Conference on Sustainable Urbanization (ICSU 2010), December, 15-17.

Matuschke, I. (2009). Rapid urbanization and food security : Using food density maps to identify future food security hotspots. International Association of Agricultural Economists Conference, 1-15.

McHarg, I. (1969). Design with Nature. John Wiley \& Sons, Inc.

Ministry of Rural and Regional Development. (2015). Malaysia Fundamental Data. In Ministry of Rural and Regional Development Official Portal. http:/www.rurallink.gov.my/wp-content/uploads/2015/05/1-DATA-ASASMALAYSIA1.pdf

NoranizaYusoff. (2015). Food Production and Management in Malaysia. International Journal of Humanities and Social Science Invention ISSN (Online, 4(8), 23197722. www.ijhssi.org

Olaniyi, A. ., Abdullah, A. M., Ramli, M. F., \& Sood, A. M. (2013). Agricultural Land Use In Malaysia: An Historical Overview And Implications For Food Security. Bulgarian Journal of Agricultural Science, 19(1), 60-69.

Osman, S., Abdullah, J., \& Nawawi, A. H. (2012). Cost of Urban Sprawl in Malaysia. 6th International Real Estate Research Symposium (IRERS), 1-16.

Rashid, M. F. A., \& Ghani, I. A. (2007). Analisis Interaksi Migrasi dan Pertumbuhan Bandar di Wilayah Lembang Klang, Malaysia menggunakan Model Komponen Berganda. Seminar Kebangsaan Rupa Bandar Malaysia: Lumut Perak, 2003, 110.

Rezai, G., Shamsudin, M. N., \& Mohamed, Z. (2016). Urban Agriculture: A Way Forward to Food and Nutrition Security in Malaysia. Procedia - Social and Behavioral Sciences, 216(October 2015), 39-45. https://doi.org/10.1016/j.sbspro.2015.12.006

Rosni, N. A., \& Mohd Noor, N. (2016). A Review of Literature on Urban Sprawl: Assessment of Factors and Causes. Journal of Architecture, Planning \& Construction Management, 6(1), 12-35. https://doi.org/10.20959/wjpps201697546

Samat, Naimah, Ghazali, S., Hasni, R., \& Elhadary, Y. A. E. (2014). Urban Expansion and its Impact on Local Communities : A Case Study of Seberang Perai , Penang 
, Malaysia. Pertanika Journal of Social Sciences \& Humanities, 22(2), 349-367.

Samat, Narimah, Ghazali, S., Hasni, R., Abdallah, Y., \& Hadary, E. (2012). Tekanan Pembangunan Di Seberang Perai Tengah Pulau Pinang: Peluang Dan Cabaran Kepada Masyarakat Tempatan. Jurnal Perspektif, 4(2), 67-84.

Seto, K., \& Ramankutty, N. (2016, May). Hidden linkages between urbanisation and food systems. Science, 352(6288), 943-945. https://doi.org/DOI: 10.1126/science.aaf7439

Siong, H. C. (2008). Urban Governance and Rapid Urbanization Issues in Malaysia. Jurnal Alam Bina, 13(4), 1-24.

Tessem, B., Bjørnestad, S., Chen, W., \& Nyre, L. (2015). Word cloud visualisation of locative information. Journal of Location Based Services, 9(4), 254-272. https://doi.org/10.1080/17489725.2015.1118566

The Economist Intelligence Unit. (2017). Global Food Security Index. In Global Food Security Index. http://foodsecurityindex.eiu.com/

The Office Of Chief Statistician Malaysia. (2017). Supply and Utilization Accounts Selected Agricultural Commodities, Malaysia 2012-2016. In Department of Statistics Malaysia Official Portal. Department of Statistic Malaysia. https://www.dosm.gov.my/v1/index.php? $r=$ column/cthemeByCat\&cat=164\&bul id=UDROQ1lWME5ETGZrcUE5VnAzcHJEQT09\&menu_id=Z0VTZGU1UH BUT1VJMFlpaXRRR0xpdz09

Tripathi, S., \& Rani, C. (2017). The impact of agricultural activities on urbanization: Evidence and implications for India. Munich Personal RePEc Archieve, 10679.

Wilson, B., \& Chakraborty, A. (2013). The environmental impacts of sprawl: Emergent themes from the past decade of planning research. Sustainability (Switzerland), 5(8), 3302-3327. https://doi.org/10.3390/su5083302

Wohlin, C. (2014). Guidelines for snowballing in systematic literature studies and a replication in software engineering. 8th International Conference on Evaluation and Assessment in Software Engineering. https://doi.org/10.1145/2601248.2601268

Wong, L. C. Y. (2007). Food Security and Growth: Malaysia's Startegic Approach and Future Adjustment. In S. A. Chin \& Y. H. Sen (Eds.), 2nd Series of ASM Biotechnology and Agriculture Forums: Food Security (pp. 55-67). Akademi Sains Malaysia. http://www.isis.org.my/attachments/438 LW Food Security Bk09.pdf

World Food Program. (2017). At the root of exodus: Food security, conflict and international migration.

Yaakob, U., Masron, T., \& Masami, F. (2010). Ninety Years of Urbanization in Malaysia : A Geographical Investigation of Its Trends and Characteristics. Journal of Ritsumeikan Social Sciences and Humanities, 4(3), 79-101. https://doi.org/10.1007/978-1-4020-4385-7 3

Yaakup, A., Muhamad, A. N., Johar, F., \& Man, N. C. (2008). Criteria For Urban Sprawl/ Land Use Expansion. Jabatan Perancangan Bandar Dan Wilayah Fakulti Alam Bina. https://doi.org/10.15713/ins.mmj.3

Received: January 2020. Accepted: $16^{\text {th }}$ May 2020 